International Journal of Linguistics, Literature and Translation

ISSN: 2617-0299 (Online); ISSN: 2708-0099 (Print)

DOI: $10.32996 / \mathrm{ijllt}$

Journal Homepage: www.al-kindipublisher.com/index.php/ijltt

IJLLT

\title{
Representing The National Identity Through Foreignization in The English Translation of Selected Indonesian Children's Literature
}

\author{
Almira Ghassani Shabrina Romala \\ English Letters Department, Universitas Sanata Dharma, Yogyakarta, Indonesia \\ $\square$ Corresponding Author: Almira Ghassani Shabrina Romala, E-mail: almiraromala@usd.ac.id
}

\begin{abstract}
ARTICLE INFORMATION
Received: 17 October 2021

Accepted: 16 November 2021

Published: 30 November 2021

DOI: $10.32996 /$ ijllt.2021.4.11.16
\end{abstract}

\section{KEYWORDS}

National identity, foreignization, literary translation, children's literature

\section{ABSTRACT}

National identity can be reflected by distinctive traditions, culture, and language and is found in literary works. However, the issue is that whether translated literature can maintain the national identity of the original works. Therefore, to answer this problem, this research aims to investigate categories of foreignization in the English translation of selected Indonesian children's literature. Besides, it further unravels the applied methods in explaining the foreignization found to determine the purpose and whether it can maintain the national identity of the original. This research was conducted through a descriptive qualitative approach. The data were collected through document analysis utilizing content and thematic analysis. The research results illustrate the categories of foreignization identified in the novel, such as terms of address, exotic fruits, traditional foods, fabric and clothes, and Javanese expressions. The applied methods in explaining the foreignization, i.e., footnotes and in-text descriptions, are then studied under the readers' response approach to determine the appropriateness and success in maintaining the national identity. This study concludes that the foreignization done by the translators to keep the identity in the works aims to introduce and promote local Indonesian culture in how people address others, the richness of local fruits, foods, and clothes. It also presents Javanese expression to specifically expresses specific terms or feeling to the wider audience and readers. Footnotes and in-text descriptions as translator notes add more illustrations of the foreignization for the readers while showing the national identity.

\section{Introduction}

Identity is a part of someone's character that distinguishes them from other people in this vast world. There are several kinds of identity embodied in an individual, one of them is national identity. National identity can be reflected by distinctive traditions, culture, and language and found in literary works. Literary works hold the national identity from how it is written and produced. It also shows the identity of the author and the culture reflected in the works. This identity issue would not be without a problem, notably if the discussion covers translated literature or literary translation. It is an arduous challenge to explore and maintain the identity-particularly national identity—in a translated literary work.

The identity embodied in a literary work is as essential as an identification card held by any citizen-the identity in literary work functions as the central message towards its audience. The message is problematizing recent issues in this world, such as people's wellbeing, tolerance, living environment awareness, and even response to the current Covid-19 pandemic. Troubles will come if the identity is missing. It is like a body without a name and soul. Therefore, it is considered necessary to cover this discussion in preserving national identity in translated literary works. The issue is that whether translated literature can maintain the national identity of the original works.

To assess the national identity maintenance in translated literary works, the focus can be directed to the notion of bridging the cultural difference between the source language and target language of the translation. One of the most challenging problems in translating is found in the differences between cultures, the source language $(\mathrm{SL})$ culture, and that of the target language (TL)

Copyright: (c) 2021 the Author(s). This article is an open access article distributed under the terms and conditions of the Creative Commons Attribution (CC-BY) 4.0 license (https://creativecommons.org/licenses/by/4.0/). Published by Al-Kindi Centre for Research and Development, London, United Kingdom. 
because, as stated by Larson in Morina (2013), different cultures have different focuses. The notion of 'cultural term' is prevalent in translation, especially in literary translation. For example, Newmark in Widiatmi (2014) states that culture refers to the way of life and its peculiar manifestations to a community that uses a particular language as its means of expression. He further says that cultural focus leads to translation problems since there is a cultural gap or distance between the SL and TL. Two fundamental ideologies of translation, domestication, and foreignization, should be applied to cope with cultural terms. The ideologies are closely related to linguistic and cultural points of view. In the domesticating translation, a translator attempts to produce a target language translation as naturally as possible. They try to minimize the strangeness of the foreign text in the SL for TL readers through a transparent and fluent style of translation that the TL readers feel like reading an original text, not a translated one. On the contrary, in foreignization, a translator attempts to take the TL readers to the foreign culture of the SL and make them feel linguistic and cultural differences. Here, the TL readers can recognize that they are not reading an original text but that translated. Domestication and foreignization are often considered ideologies, strategies, or translation methods in many books and articles. When the translators believe that their translation is acceptable and correct, domestication and foreignization are considered ideologies.

This research focuses on viewing foreignization as the ideology of translation in representing the national identity applied in the English translation of selected children's literature, Reda Gaudiamo's The Adventures of Na Willa. Children's literature was taken into consideration as the object of the research as in this kind of literature, the message and ideologies are expected to be clear and explicit -without any complicated implications- for the children -as targeted readers- understand them directly without any difficulties. It is frequent to find current global issues in children's literature.

In other words, this research is aimed at investigating categories of Indonesian cultural terms maintained in the English translation, explaining techniques of translation applied in the translations, and analyzing foreignization ideologies of translation involved to reveal the purpose of employing the foreignization to determine the maintenance of the national identity in the translation. Based on the issues mentioned in the background of the study, the researchers formulate research questions as follows:

a. What is the classification of the culture-bound items found in the foreignization in Reda Gaudiamo's The Adventures of Na Willa?

b. What methods are applied in explaining the foreignization in Reda Gaudiamo's The Adventures of Na Willa?

c. What are the purposes of employing foreignization in Reda Gaudiamo's The Adventures of Na Willa?

Thus, the first objective of this study is to investigate the categories of foreignization found, i.e., the Indonesian cultural terms maintained in the English translation. Furthermore, the following research objective is to explain the method of describing foreignization also the purpose of employing foreignization to determine the maintenance of the national identity in the translation. The analysis will be further conducted by involving respondents to assess the preferred methods of describing foreignization for the better-translated literature and readers' response. The analysis result is expected to answer the notion of viewing foreignization as the ideology of translation in representing the national identity found in the English translation of selected children's literature, Reda Gaudiamo's The Adventures of Na Willa. This research is expected to enrich translation studies repertoire, especially in the variety of foreignization occurring in translation, and provide a better understanding of the importance of audience design in the translation process. For translators and publishers, the result of this research can be used to consider the importance of the readers' response in the translation products.

\section{Literature Review}

The researcher uses two related studies to compare the analysis with this present study that discusses the foreignization of the English translation. The first related study is Jalaly and Pishkar's A Study of Domestication and Foreignization Strategies of CulturalSpecific Items in Translation of Science Fiction Literature. The present research is a qualitative study of the translation of CulturalSpecific Items in Science-fiction from English into Persian. This study aims to explore how translators domesticate or foreignize, in different cultural domains, by other means, to different extents, with varying degrees of consistency in translation of English version of French author (Jules Verne) into Persian in Science Fiction Literature. For this purpose, twelve chapters of two English versions of Jules Verne books were selected, based on some theories proposed by Espindola and Vasconcellos and Molina and Albir's models of translation by contrasting each ST-TL pair as the unit of translation, one hundred and ninety-two instances of CulturalSpecific Items extracted and classified into procedures of Domestication and Foreignization Translation Strategies that proposed by Molina and Albir. According to the result of the study, foreignization strategy is the superior strategy in translating English into Persian of Culture-Specific Items in Science Fiction Literature. However, putting aside the calque procedure can be seen as slightly different between domestication and foreignization strategies.

The second related study is Ahmadi and Nosrati's research entitled "Domestication and Foreignization Strategies in Translation of Culture-Specific Items: in Translations of English-Persian Children's Literature." They argue that culture-bound elements such as 
proper names, food items, and idioms place the story in a specific culture and period and imply certain values. These elements also affect how the reader identifies with the story and characters. It is essential to find the most appropriate strategy to translate such elements. Their paper aims to determine the most frequently used technique in translating culture-specific items in children's literature. They employ Venuti's model of domestication and foreignization strategies as adopted as the framework. The culturebound terms were classified based on toponyms, anthroponyms, means of transportation, date, food, drink, idioms, measuring system, educational reference. According to the obtained results, although domesticating and foreignizing strategies have been used, the most dominant cultural translation strategy is in children's literature.

Therefore, the result of the two previous related studies strengthens the notion that foreignization holds a significant role in translated children's literature as it has been the most dominant strategy in delivering culture-specific or culture-bound items. Therefore, by analyzing this foreignization in the English translation of selected children's literature, it is expected that the representation of Indonesian as a national identity can be revealed.

\subsection{Foreignization}

In the 1970s, at the forum of contemporary international translation, Venuti was recognized as the representative of foreignization. He proposed the concept which gave prominence to the foreignness of the source text, either in style or any other aspects contained in the source text language. In this type of translation, readers are urged to accept foreign cultural concepts. Translators do not compromise with the readers.

Venuti was not the first to introduce foreignization. The term foreignization strategy can be traced back to the German culture of the Classical and Romantic periods, as Schleiermacher proposed it. Schleiermacher presents foreignization because of the intended readership and because it can benefit the target text language. Schleiermacher prefers foreignization as he states that the translator leaves the writer alone as much as possible and moves the reader towards the writer (Munday, 2008: 147).

When foreignization is used, culture-specific items containing cultural information of the source text language will be preserved. The readers will feel the atmosphere and sense of the source text language culture to a greater degree. However, it should be understood that foreignization is not a simple translation from word to word. Foreignization only retains particular source text language, which conveys the semantically structured concept. They are primarily concerned about culture-specific items.

In the case of translator visibility, Venuti strongly prefers the foreignizing strategy as it makes the translators visible to the readers, leading to the recognition of the translators. Upon reading, readers will find some foreign concepts which are retained in the target text. This eventually makes the target text readers aware of the foreign source text elements which are preserved. Target text readers will be mindful of the existence of the source text in another language and, eventually, realize the translator's presence.

Venuti recommends foreignization as he argues that it is unfair to use domestication. Venuti (1995: 20) states that domestication involves an ethnocentric reduction of the foreign text to the target-language cultural values. In domestication, foreign cultural values are excluded or adapted to fit into the domestic value system of the target text language. Foreignization translation is also slowly accepted by the readers. The foreignization in translation plays a more vital role as it deepens communication between various countries. Target text readers will have the chance to know the culture of the source text language, and the target text language will be able to enrich itself. As we all know, language is not a sealed system; consequently, a good foreignization in translation is undoubtedly advantageous to improve the target text language. Foreignization will allow the target text language to absorb some new language elements of the source text language. Once specific vocabularies or culture-specific items are accepted by society, they will gradually be regarded as new members of the target text languages.

\subsection{Translator Notes for Foreignization}

There are various ways to add notes to a translation. Popular methods include simply using parentheses inserted directly into the text or prefixing a comment. Using footnotes is also a popular method among translators, although if the source text already contains footnotes, this method may confuse. When using the abbreviated form, be sure to write out 'Translator's note' in full first, as this will ensure the reader is clear about the abbreviation's meaning. Whatever method you choose to alert readers to your notes, the main thing is to be consistent with your usage to send a clear signal to the reader.

Suppose the notes are only intended for a client to read and not published in the final text of the target translation. In that case, it's appropriate, and perhaps more convenient, to use the comment function of various word processing software. This will alert the client to different issues they need to follow up with you or consider by themselves before publishing the translation.

How frequently are the translator's notes appropriate to use? A popular point of debate among translators is how often they should use notes. After all, providing detailed notes explaining your decisions will eat into your translation time. 
This was discussed in detail on the Proz discussion forum. A translator provided detailed notes for each interpretive option she chose and then requested how she justified her selected translation. What complicates matters further was that she was transcribing an audio recording that contained several informalities and redundancies.

\subsubsection{Footnotes and Endnotes}

The translator adds footnotes and endnotes to the target text to provide additional information about the limits of the translation, the cultural background, or any other explanations. Translator notes are also used to potential flag mistakes in the source text or difficulties during the translation. If a translator feels to have to use a footnote, they usually do it once per word or phrase. They use foreignization and translator notes if it is essential and there is no cognate to the language they are writing in. If the novel is peppered with notes, it will feel more like an academic book than a story. Thus, the appropriate number of using translator notes is essential, particularly in children's literature.

A footnote is a reference or comment at the bottom of a page or end of a chapter; direction to a comment which appears in the continuation of a document add a footnote to a text. The use of footnotes (or endnotes) is part of the tendency towards exploiting the translation. Id work's content can be helpful to, useless or harmful, depending on the type of reader one addresses. Systematic or uncontrolled explicitation is, in any case, condemnable because it ends up being applied even when the translator is unaware of doing so.

Among the researchers siding against footnotes, let us read, for example, what Umberto Eco writes in his beautiful book in which he covers his own experiences as a translator and translated author:

There are losses that we could consider absolute. They are the cases when it is not possible to translate. If such cases occur, it is supposed, in the middle of a novel, the translator falls back on the ultima ratio, introducing a footnote - and then the footnote ratifies her defeat. Many wordplays provide an example of total loss.

In this case, Eco could not have a detached tone, being the author of the texts used as examples. The moment when he speaks about the notes to translations of his texts, it is not the semiotician who prevails; it is the author, whose intention (the well-known intentio auctoris that for dead or inaccessible authors is at the center of many discussions among the interpreters of their work) if expressed by the author himself, is indisputable."

In clarifying or giving more description for a foreign term, a translator can use translator notes. The translator adds translator notes or the target text to provide additional information about the limits of the translation, the cultural background, or any other explanations. 'How frequent the translator notes are appropriate to use is still a popular point of debate among translators. There are various ways to add notes to a translation, such as footnotes, endnotes, in-text descriptions, or glossaries. The first is an in-text description. In this method, the translator clarifies or adds the definition of the foreign terms inside the text or paragraph. It is usually marked with sentences in italic. Next, footnotes are a reference or comment at the bottom of a page. Meanwhile, endnotes are a reference or statement at the end of a chapter. The last one, a glossary, is often found at the end of the book; it serves as a mini dictionary with a list of foreign terms in the book with the definition.

\section{Methodology}

\subsection{Research Object}

Published April 11th, 2019 by The Emma Press, the novel The Adventures of Na Willa written by Reda Gaudiamo tells about a little girl's life named Na Willa. Na Willa is a bright, adventurous girl living in Surabaya's suburbs, her home in the middle of an alley surrounded by cypress trees. She spends her days running after trains with Dul (she always beats him), going down to the market with Mak, and thinking about how people can sing through radios. But while everyone else tells Na Willa what to do and who to be, Na Willa wants to be free. She doesn't want to be "just" a girl. She doesn't want to look just like Pak or just Mak. She wants to be both and more.

Indonesian author Reda Gaudiamo has created a collection of stories of curious adventures and musings of a multicultural girl growing up in Indonesia with an East Indonesian mother and a Chinese-Indonesian father. Set in a time when children spent the day outside, listening to Lilis Suryani's songs on the radio, and when race and gender would still go undiscussed, this is Na Willa's story as she grows up unafraid to ask the big questions.

As telling a story of a multicultural girl, Na Willa presents large cultural-specific items in the novel. It pays great attention and roles throughout the storyline. Moreover, it is essential to analyze how the culturally specific items are translated in foreignized terms and to determine the translator's purpose in doing so. Therefore, this research was aimed to investigate the tegories of foreignized 
terms in Reda Gaudiamo's The Adventures of Na Willa, unraveling the applied methods in explaining the foreignized terms by comparing the original work Na Willa and its English translation, The Adventures of Na Willa.

\subsection{Research Approach}

This research was conducted through a descriptive qualitative approach. It is qualitative in which the researcher observes the use of foreignization in translating culture-specific items found in the research object. The Indonesian foreignized ter used in this research is from Na Willa and its English translation, The Adventures of Na Willa. The data are collected through document analysis involving skimming (superficial examination), reading (thorough examination), and interpretation. This method consists of content analysis and thematic analysis. The former refers to the process of organizing information into categories related to the central questions of the research (Bowen, 2009), while the latter refers to a form of pattern recognition within the data, with emerging themes becoming the categories for analysis (Fereday \& Muir-Cochrane in Bowen, 2009). Besides, Leedy and Ormrod in Williams (2007) have stated that content analysis is a detailed and systematic examination of the contents of a particular body of materials. It is aimed at identifying patterns, themes, or biases. Williams (2007) further states that content analysis reviews forms of human communication, including books, newspapers, films, and other documents. The data source in this research is repeatedly and carefully read to find out information on cultural words, phrases, or expressions in the SL text and their translations in the TL. The occurrences of the Indonesian cultural terms are then classified following the categories of culture as qualitative evidence. The researcher also uses theories available to analyze the foreignization strategies, culture-specific items, and the translation procedures applied by the translators. The translation techniques and ideologies applied in the translations of the Indonesian cultural terms are then analyzed descriptively.

The mixed-methods, which are qualitative and quantitative methods, are applied in this research. As stated by Mary W. George in Types of Research Method (2008: 5), the "qualitative method designates any research whose results are captured in words, images, or non-numeric symbols". The qualitative method applied in this research was the library method. According to George, the characteristic of the library method is that "it involves identifying and locating source that provides factual information or personal or expert opinion on a research question". In the library method, researchers use several theories and related studies to compare with the current research.

Moreover, as defined by George, quantitative research is "to describe any approach in which the phenomenon under study is captured via measurement and expressed in numbers that can be analyzed". The quantitative method applied in this research is survey methods. According to George, the characteristic of the survey method is that "it poses some question to a group of people with specific responses for the individuals to choose from". An example of this method is written questionnaire distribution. For this survey method, the researchers distribute questionnaires to respondents containing the methods in explaining the foreignization found in the translated novels. After the data from respondents are collected, the researchers use the data to find out the answers from this research problem formulation which are the foreignization and its purpose of employment in representing the national identity of Indonesia.

\subsection{Methodology}

Before collecting the data, the researchers first read the novels in English and then the original, i.e., Indonesian versions. The researchers find that there is much foreignization in the English translation novel. These terms were explained using several methods such as in-text description, footnotes, endnotes, and glossary.

The researcher collected the data by underlining the phrases and sentences that contain foreignization in TT and checking for the original version in ST. While highlighting these terms, the researchers also put the data from the English and Indonesian versions into the column on the table in Microsoft Word. These terms are going to be distinguished between the terms in the English version and the Indonesian version. The English terms are placed in the left column titled "TT". The original Indonesian version of foreignization titled "ST" is placed in the right column. Furthermore, the researchers encode the ST and TT data, as exemplified in the following:

\begin{tabular}{|l|l|l|l|}
\hline No. & ST & TT & Explanation \\
\hline 1 & Noni & Noni & *Noni/Non - an affectionate way of addressing a young girl \\
\hline 2 & sawo & sawo & $\begin{array}{l}\text { *sawo - a kind of yellow-brown berry fruit, about the size and shape of a } \\
\text { kiwi fruit, that has the texture of a pear and is deliciously sweet }\end{array}$ \\
\hline 3 & sambal & sambal & *sambal - a delicious spicy relish served alongside savoury foods \\
\hline
\end{tabular}


After collecting and encoding the data, the researcher analyzed the foreignization by comparing the sentences from ST and TT. The methods of the translator notes are also analyzed to determine the function of the use of both foreignization and the specific method in explaining the foreign terms.

\begin{tabular}{|c|c|c|c|c|}
\hline No. & ST & TT & Foreignization & Translator Notes \\
\hline 1 & $\begin{array}{l}\text { "Tidak bisa, Noni! Kamu perempuan. } \\
\text { Perempuan!" }\end{array}$ & $\begin{array}{l}\text { 'That's impossible, Noni. } \\
\text { You're a girl. A girl!' }\end{array}$ & Noni & $\begin{array}{l}\text { Noni/Non - an affectionate way } \\
\text { of addressing a young girl }\end{array}$ \\
\hline 2 & $\begin{array}{l}\text { Menemani Mak menuju dapur, dari tas } \\
\text { belanja dari plastik yang berlubang- } \\
\text { lubang itu, ada sawo menyembul. }\end{array}$ & $\begin{array}{l}\text { Inside a plastic shopping } \\
\text { bag, some sawo fruits are } \\
\text { poking out. }\end{array}$ & sawo & $\begin{array}{l}\text { sawo - a kind of yellow-brown } \\
\text { berry fruit, about the size and } \\
\text { shape of a kiwi fruit, that has the } \\
\text { texture of a pear and is } \\
\text { deliciously sweet }\end{array}$ \\
\hline 3 & Bunganya diiris, jadi sambal. & $\begin{array}{l}\text { Or we cut up some } \\
\text { hibiscus petals and squish } \\
\text { them into sambal. }\end{array}$ & sambal & $\begin{array}{l}\text { sambal - a delicious spicy relish } \\
\text { served alongside savoury foods }\end{array}$ \\
\hline
\end{tabular}

The original sentences in the Indonesian version are compared with the sentences in the English translation that contains foreignization. The foreign terms are then identified and put in the column. The translator notes are also collected to determine whether the foreignization and the notes can show the national identity in the translated version of $\mathrm{Na}$ Willa.

\subsection{Population and Sample}

After reading and collecting the data, the foreignization found in the novel is about 100 data. Not all the data are analyzed due to the foreignization found is sometimes repeated. The data are selected purposively to make the analysis effective because the specific categorization is available from the source text. Therefore, the researchers have collected the data from each chapter in the novels. The chosen data are the data that are easy to understand and use in many chapters. Moreover, the researcher selects the data by considering the terms that are used mainly in the books. The collected data are placed in a separate column containing the source language and target language. Then the researchers compare the foreignization in the column SL and TL to determine the classification and purpose of the foreignization and determine the applied method of explaining the terms.

\section{Results and Discussion}

This research focuses on viewing foreignization as the ideology of translation in representing the national identity. I took the English translation of Reda Gaudiamo's Na Willa as an example for this case. Children's literature was taken into consideration as the object as in this kind of literature, the message and ideologies are expected to be clear and explicit -without any complicated implications- for the children as targeted readers, they will be able to understand them directly without any difficulties.

The second edition of Na Willa was published in 2018 by POST Press. The English translation based on this version was published in 2019 by The Emma Press. The short story collection The Adventures of Na Willa tells about a little girl life named Na Willa around the 1960s in Surabaya, Indonesia.

Na Willa is a collection of stories of curious adventures and musings of a multicultural girl growing up in Indonesia with an East Indonesian mother and a Chinese-Indonesian father. Set in a time when children spent the day outside and when race and gender would still go undiscussed, it tells Na Willa's story as she grows up unafraid to ask the big questions.

As telling a story of a multicultural girl, Na Willa presents large cultural-specific items in the story. It pays great attention and roles throughout the storyline. Therefore, our discussion is aimed at investigating categories of foreignization in Reda Gaudiamo's The Adventures of $\mathrm{Na}$ Willa, unraveling the applied translator notes in explaining the foreignization by comparing the original work of $\mathrm{Na}$ Willa and its English translation, The Adventures of $\mathrm{Na}$ Willa, then ultimately observing whether the national identity is maintained in the translation.

From the findings and analysis, in The Adventures of $\mathrm{Na}$ Willa, there are at least five categories of foreignization: terms of address, fruits, clothes, and traditional foods, which are explained in footnotes Javanese expressions that use in-text description. 


\subsection{Terms of Address}

The first type of foreignization in terms of address reveals how $\mathrm{Na}$ Willa, as the main character calls the other characters in the story. The use and function of each term of address are conveyed in the footnotes. The examples are shown in the following table.

\begin{tabular}{|c|c|c|c|c|}
\hline No. & ST & TT & Foreignization & Translator Notes \\
\hline 1 & $\begin{array}{l}\text { Kalau aku besar nanti, aku ingin } \\
\text { bisa setinggi Pak. }\end{array}$ & $\begin{array}{l}\text { When I grow up, I want to be as } \\
\text { tall as Pak. }\end{array}$ & Pak & Pak - dad \\
\hline 2 & $\begin{array}{l}\text { Tapi aku mau rambutku bisa } \\
\text { seperti Mak. }\end{array}$ & $\begin{array}{l}\text { I want to be as tall as Pak but I } \\
\text { want my hair to grow like Mak's. }\end{array}$ & Mak & Mak - mum \\
\hline 3 & $\begin{array}{l}\text { Waktu aku bilang ini pada Mbok, } \\
\text { dia tertawa terbahak-bahak. }\end{array}$ & $\begin{array}{l}\text { When I try to say this to Mbok, } \\
\text { she laughs out loud. }\end{array}$ & Mbok & Mbok - a household assistant \\
\hline 4 & $\begin{array}{l}\text { "Tidak bisa, Noni! Kamu } \\
\text { perempuan. Perempuan!" }\end{array}$ & $\begin{array}{l}\text { 'That's impossible, Noni. You're a } \\
\text { girl. A girl!' }\end{array}$ & Noni & $\begin{array}{l}\text { Noni/Non - an affectionate way } \\
\text { of addressing a young girl }\end{array}$ \\
\hline
\end{tabular}

In the examples above, the foreign terms are Pak, Mak, Mbok, and Noni. Pak is how Na Willa calls her father. The term Pak is a shortened form of Bapak which means 'father' in Javanese or Bahasa Indonesia. Bapak is a common term to call father in Indonesia. Meanwhile, Na Willa calls her mother Mak, and this term is maintained in the English translation as a foreignization. The word comes from Javanese words to call 'mother', i.e., Mak, Emak, or Mamak. Mbok is from the Javanese language, which also means 'mother', but in this context, it is used to call a household assistant, differentiating how Na Willa calls her mother. This term of address is common to reach an older woman. Meanwhile, Mbok calls Na Willa her little master, Noni. It is often used to call someone younger with a higher position in an affectionate way. These terms of address also show the status and social system that exist in Indonesia, differentiating who the master and the assistant are. Furthermore, it shows typical Indonesian culture that each has a specific term of address for calling older people. It is not common to find Indonesians calling older people only by their names unless they ask to or are already close. Thus, foreignization is very important to display the Indonesian culture and social system.

\subsection{Fruits}

Some of the fruits are used in foreign terms; they are sawo, salak, and srikaya. Footnotes are also used as a way to clarify and describe these Indonesian fruits. The translator notes add a detailed description of sawo with some adjectives like 'deliciously sweet' to make the readers interested, as seen in the table below.

\begin{tabular}{|l|l|l|l|l|}
\hline No. & ST & TT & Foreignization & Translator Notes \\
\hline 1 & $\begin{array}{l}\text { Menemani Mak menuju dapur, } \\
\text { dari tas belanja dari plastik yang } \\
\text { berlubang-lubang itu, ada sawo } \\
\text { menyembul. }\end{array}$ & $\begin{array}{l}\text { Inside a plastic } \\
\text { shopping bag, some } \\
\text { sawo fruits are } \\
\text { poking out. }\end{array}$ & $\begin{array}{l}\text { sawo - a kind of yellow-brown berry fruit, } \\
\text { about the size and shape of a kiwi fruit, that } \\
\text { has the texture of a pear and is deliciously } \\
\text { sweet }\end{array}$ \\
\hline 2 & Salak, srikaya, mainan? & $\begin{array}{l}\text { Salak? Srikaya? A A } \\
\text { toy? }\end{array}$ & $\begin{array}{l}\text { salak - sometimes called 'snake fruit', salak is } \\
\text { a tasty fruit with soft white flesh inside but a } \\
\text { brown scaly skin that (you guessed it) looks } \\
\text { and feels like snakeskin }\end{array}$ \\
\hline 3 & Salak, srikaya, mainan? & $\begin{array}{l}\text { Salak? Srikaya? A } \\
\text { toy? }\end{array}$ & srikaya & $\begin{array}{l}\text { srikaya - another fruit, sometimes called } \\
\text { 'custard apple' }\end{array}$ \\
\hline
\end{tabular}

The fruit sawo is described in detailed features such as a kind of yellow-brown berry fruit, about the size and shape of a kiwi fruit, which has a pear texture and is deliciously sweet. This delineation helps readers who have not seen, touched, and taste sawo to imagine the fruit. The adjective 'deliciously sweet 'adds the curiosity towards the readers in knowing more about this Indonesian fruit as it is also one of Na Willa's favorite fruits. Although there have been common counterparts of salak and srikaya in English, the translators maintain the local name instead of 'snake fruit' or 'custard apple'. The translators also add some descriptions to aid the readers in getting to know more about these fruits. By employing foreignization in this type, the readers will know that these fruits are common in Indonesia. 


\subsection{Clothes}

Some examples of foreignization in the clothes category are kain, selendang, sarung, kopiah, and batik. The translators show the national identity by using the 'keywords' like Indonesia and Southeast Asia in the footnotes seen in the table as follows.

\begin{tabular}{|c|c|c|c|c|}
\hline No. & ST & TT & Foreignization & Translator Notes \\
\hline 1 & $\begin{array}{l}\text { lbunya selalu memakai kain } \\
\text { dan selendang yang } \\
\text { disampirkan di kepala. }\end{array}$ & 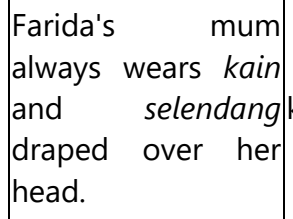 & kain, selendang & $\begin{array}{l}\text { kain - the word kain simply means 'cloth', but } \\
\text { here it is used to describe a length of cloth } \\
\text { wrapped around the waist like a sort of skirt } \\
\text { selendang - a long scarf worn around the waist } \\
\text { or over the head }\end{array}$ \\
\hline 2 & $\begin{array}{l}\text { Bapaknya selalu memakai } \\
\text { sarung, berikat pinggang } \\
\text { lebar. }\end{array}$ & $\begin{array}{l}\text { While } \text { Farida's dad } \\
\text { always wears a } \\
\text { sarung (instead of } \\
\text { trousers) held up } \\
\text { with a big belt. }\end{array}$ & & $\begin{array}{l}\text { sarung - another piece of clothing worn in } \\
\text { Indonesia that is a long length of cloth wrapped } \\
\text { around the body and tied either at the waist or } \\
\text { below the armpits }\end{array}$ \\
\hline 3 & $\begin{array}{l}\text { Kopiah tak pernah lupa, tetapi } \\
\text { dipakai melebar di kepala. }\end{array}$ & $\mid \begin{array}{lr}\text { He also never } \\
\text { forgets to put } \\
\text { kopiah on his head. }\end{array}$ & & $\begin{array}{l}\text { kopiah - a cap mostly worn by Muslim men and } \\
\text { found all over Southeast Asia }\end{array}$ \\
\hline 4 & $\begin{array}{l}\text { Di dalam duduk seorang } \\
\text { perempuan agak tua-tapi } \\
\text { lebih muda dari Nyonya Chang } \\
\text { dan Mbok-duduk di } \\
\text { belakang sebuah meja yang } \\
\text { ditutup taplak batik. }\end{array}$ & $\begin{array}{l}\text { She sits on a chair } \\
\text { behind a table that } \\
\text { is covered with } \\
\text { batik cloth. }\end{array}$ & batik & $\begin{array}{l}\text { batik - a traditional Indonesian way of } \\
\text { decorating cloth, where complex designs are } \\
\text { drawn onto cloth with melted wax and then the } \\
\text { cloth is dipped in dye. The parts of the cloth } \\
\text { which were drawn on with wax don't absorb the } \\
\text { dye, so when the wax comes off you have a } \\
\text { pattern. }\end{array}$ \\
\hline
\end{tabular}

Batik is already familiar to people outside Indonesia, yet the translators still explain it. The translator notes for batik hint that batik is from Indonesia with its detailed description of the making. Therefore, it functions to introduce and promote batik as one of the Indonesian cultures.

\subsection{Foods}

There are several names for foods that are maintained and used in foreignization in the English version of Na Willa. The translators utilize footnotes in explicating the foods for the readers. Some of the examples can be found in the following table.

\begin{tabular}{|c|c|c|c|c|}
\hline No. & ST & TT & Foreignization & Translator Notes \\
\hline 1 & $\begin{array}{l}\text { Bunganya diiris, jadi } \\
\text { sambal. }\end{array}$ & $\begin{array}{l}\text { Or we cut up some hibiscus petals } \\
\text { and squish them into sambal. }\end{array}$ & sambal & $\begin{array}{l}\text { sambal - a delicious spicy relish } \\
\text { served alongside savoury foods }\end{array}$ \\
\hline 2 & $\begin{array}{l}\text { Kadang-kadang kami } \\
\text { buat pecel. Bumbunya } \\
\text { pakai bata merah yang } \\
\text { ditumbuk halus. }\end{array}$ & $\begin{array}{l}\text { Sometimes we make pecel with } \\
\text { these fine green beans. We make } \\
\text { the spices for the pecel by grinding } \\
\text { up bits of red brick into a dusty } \\
\text { powder. }\end{array}$ & pecel & $\begin{array}{l}\text { pecel - a Javanese vegetable stew } \\
\text { served with a spicy peanut sauce }\end{array}$ \\
\hline 3 & $\begin{array}{l}\text { Mak selalu memberinya } \\
\text { minum. Kadang-kadang, } \\
\text { semangka, kue mangkok, } \\
\text { atau getuk. }\end{array}$ & $\begin{array}{l}\text { Mak gives her a glass of water } \\
\text { along with some watermelon, } \\
\text { cupcakes, or gethuk. }\end{array}$ & & $\begin{array}{l}\text { gethuk }- \text { a simple but tasty } \\
\text { Javanese dish made from cassava (a } \\
\text { starchy sort of root vegetable) }\end{array}$ \\
\hline 4 & $\begin{array}{l}\text { Ida bilang, mau bikin } \\
\text { bubur merah putih, } \\
\text { selametan ganti nama. }\end{array}$ & $\begin{array}{l}\text { Ida says she is going to cook bubur } \\
\text { merah putih, to celebrate a change } \\
\text { of name. }\end{array}$ & bubur merah putih & $\begin{array}{l}\text { bubur merah putih - 'red and white } \\
\text { porridge'. The words 'merah putih' } \\
\text { ('red white') are also used to }\end{array}$ \\
\hline
\end{tabular}




\begin{tabular}{|l|l|l|l|l|}
\hline No. & ST & TT & Foreignization & Translator Notes \\
\hline & & & & $\begin{array}{l}\text { describe Indonesia's national flag, } \\
\text { which is red and white. }\end{array}$ \\
\hline
\end{tabular}

The translator notes for pecel, gethuk, and bubur merah putih also show the identity in words Javanese and Indonesia. And even the translators use the Indonesian national flag 'merah putih' to explain the food. It is exciting and strongly shows the Indonesian identity and nationalism. Besides the previous foods, nasi goreng and krupuk are also retained in the translation. It can be seen in the following table.

\begin{tabular}{|c|c|c|c|c|}
\hline No. & ST & TT & Foreignization & Translator Notes \\
\hline 5 & Bikin cucur! & She's making cucur. & cucur & $\begin{array}{l}\text { cucur - a tasty and sweet } \\
\text { deep-fried snack, often } \\
\text { made from rice flour mixed } \\
\text { with palm sugar }\end{array}$ \\
\hline 6 & $\begin{array}{l}\text { Habis mandi, berpakaian, sisir rambut, } \\
\text { minum susu cap sapi tertawa, pakai } \\
\text { bedak, pakai kaus kaki dan sepatu, } \\
\text { memeriksa botol minum dan tromol isi } \\
\text { nasi goring ditaburi telur dadar, ambil } \\
\text { karet buta mengikat sendok di tromol. }\end{array}$ & $\begin{array}{l}\text { I have my water bottle and } \\
\text { lunch box (with nasi goreng } \\
\text { and a crispy fried egg), and I } \\
\text { use a rubber band to attach } \\
\text { a spoon to my lunch box. }\end{array}$ & nasi goreng & nasi goreng - fried rice \\
\hline 7 & $\begin{array}{l}\text { Oh, aku tahu: sarapan nasi pakai kerupuk } \\
\text { saja! }\end{array}$ & $\begin{array}{l}\text { Oh, I see: it's just white rice } \\
\text { and krupuk. }\end{array}$ & krupuk & $\begin{array}{l}\text { krupuk }- \text { Indonesian } \\
\text { prawn crackers }\end{array}$ \\
\hline
\end{tabular}

It is common to use fried rice for nasi goreng. Even we often find the term fried rice used here in Indonesia. However, the translators keep the term showing the Indonesian identity, 'fried rice is nasi goreng in Indonesia'. It differentiates Indonesian nasi goreng from any other fried rice that may be found in another country. It is also similar to krupuk. It was described that it is the special Indonesian prawn crackers. The foreignization in the food category can attract readers. They will get to know some Indonesian foods. If they come to Indonesia, they will know what to try and what to order with that richness of traditional culinary of Indonesia.

\subsection{Javanese Expressions}

Javanese expressions present in the translation are the products of foreignization. They show the localness and also the characteristics of the Javanese language. There are three Javanese expressions in the English translation, i.e.

\begin{tabular}{|c|c|c|c|c|}
\hline No. & ST & TT & Foreignization & Translator Notes \\
\hline 1 & $\begin{array}{l}\text { Tapi Mbok bilang, dari jaman } \\
\text { Pebruari (Mbok selalu bilang 'jaman } \\
\text { Pebruari' untuk semua yang serba } \\
\text { jaman dahulu kala), semua anak } \\
\text { perempuan pasti akan jadi seperti } \\
\text { bapaknya. }\end{array}$ & $\begin{array}{l}\text { Then Mbok tells me that since the days } \\
\text { of 'Pebruari' (she always says 'the days of } \\
\text { Pebruari' for anything related to the } \\
\text { OLDEN DAYS) all girls have grown up like } \\
\text { their fathers and all boys have grown up } \\
\text { like their mothers. }\end{array}$ & Pebruari & $\begin{array}{l}\text { anything related to } \\
\text { the OLDEN DAYS }\end{array}$ \\
\hline 2 & $\begin{array}{l}\text { "Ora iso! Ora iso! Wedhok, yo } \\
\text { wedhok!" kata Mbok. }\end{array}$ & $\begin{array}{l}\text { 'Ora iso! Ora iso! Wedhok, yo wedhok!' } \\
\text { says Mbok (which means No! You can't! } \\
\text { You are a girl and will forever be a girl!). }\end{array}$ & $\begin{array}{lr}\text { 'Ora iso! } & \text { Ora iso! } \\
\text { Wedhok, } & \text { yo } \\
\text { wedhok!' } & \end{array}$ & $\begin{array}{l}\text { You are a girl and will } \\
\text { forever be a girl! }\end{array}$ \\
\hline 3 & $\begin{array}{l}\text { Tapi aku juga tidak suka main } \\
\text { dengan Warno karena setiap aku } \\
\text { lewat di depan rumahnya, tanpa } \\
\text { Mak, dia pasti teriak: asu Cino! }\end{array}$ & $\begin{array}{l}\text { I didn't like playing with Warno because } \\
\text { whenever I passed by the front of his } \\
\text { house when I was alone without Mak, } \\
\text { he'd scream: Asu Cino! } \\
\text { Asu Cino means Chinese dog. }\end{array}$ & Asu Cino & Chinese dog \\
\hline
\end{tabular}


The Javanese expressions are essential as they convey the meaning and feeling while holding the attitude in Javanese culture. The in-text description is used for this foreignization as the meaning of these expressions is vital for the flow of the story and the direct readers' understanding. By putting the meaning inside the text, the readers will immediately understand it without breaking the reading pace and looking for the definition somewhere else in the book.

In addition, more readers choose footnotes with $75 \%$ and in-text descriptions with $25 \%$ from the survey conducted covering the preferred Translator Notes in Na Willa. The respondents are readers of $\mathrm{Na}$ Willa both in Indonesia and outside. The readers prefer footnotes as they can explore and describe more the foreignization of the cultural terms. Meanwhile, the detailed description inside the text is limited as it can also affect the flow of the story or narration. Some respondents also argue that footnotes directly explain the terms on the same page and do not affect the reading experience. On the other hand, an in-text description is appropriate when the foreign terms need an urgent and immediate explanation. Without the presence, it will be difficult for the readers to understand the whole context and story.

It is also in line with my previous survey, which involved 200 book lovers' community members and mostly read translated literature. Most of them prefer footnotes over the other methods of translator notes. The percentage of each technique is presented as follows.

\section{Conclusion}

To sum up, the foreignization done by the translator to maintain the national identity in the works aims to introduce and promote local Indonesian culture in how people address others, the social system, the richness of local fruits, traditional foods, and clothes. It also introduces Javanese expressions to specifically expresses specific terms or feeling to the wider audience and readers. The readers will get to know an exotic atmosphere in Indonesia, a new culture, and the characteristics of the Javanese language, which can enrich the expressions of their language. In addition, footnotes are considered an appropriate method of translator notes as they enable the translator to add more details about the cultural terms, show the identity, and at the same time make the readers thrilled and interested.

Quoting Venuti, the researcher wants to suggest that foreignization is highly desirable today. It seeks to restrain the ethnocentric violence of translation, a strategic cultural intervention in the current state of world affairs, pitched against the hegemonic Englishlanguage nations the unequal cultural exchanges. Foreignization in English can be a form of resistance against ethnocentrism and racism, cultural narcissism and imperialism, in the interests of democratic geopolitical relations. Foreignization is resistance; we introduce Indonesian culture and promote them while showing our national identity and roots.

Foreignization can be political; foreignization can be radical. The word radical comes from the Latin word radix, which means root. Foreignization is radical. It's built into our language and culture. So, let's be radical!

Funding: This research was funded by LPPM USD under the research scheme for junior lecturers and the Department of English Letters, Universitas Sanata Dharma.

Conflicts of Interest: The authors declare no conflict of interest.

\section{References}

[1] Ahmadi K and Nosrati P. (2012). Domestication and Foreignization Strategies in Translation of Culture-Specific Items: in Translations of English-Persian Children's Literature.

[2] Baker, M. (1992). In Other Words: A Coursebook on Translation. 11 New Fetter Lane, London: Routledge.

[3] Bassnett, S. (1991) Translation Studies Revised Edition. London: Routledge.

[4] Catford, J. C. A. (1965) Linguistic Theory of Translation. London: Oxford University Press.

[5] George, M. W. (2008) The Elements of Library Research: What Every Student Needs to Know. New Jersey: Princeton University Press.

[6] Hornby, A. S. (2005) Oxford Advanced Learner's Dictionary of Current English. Seventh Edition. London: Oxford University Press.

[7] Jalaly, F. and K. Pishkar. (1982) A Study of Domestication and Foreignization Strategies of Cultural-Specific Items in Translation of Science Fiction Literature.

[8] Kim, C. (1973) Statistical Analysis for Induction and Decision. Hinsdale: the University of Santa Clara, The Dryden Press Inc.

[9] Larsson, P. (2006) Classification into Readability Levels: Implementation and Evaluation. Thesis. Stockholm: Uppsala Universitet,.

[10] Munday, J. (2001) Introducing Translation Studies. Theories and Applications. Second Edition. London: Routledge.

[11] Munday, J. and B. Hatim. (2004) Translation: An Advanced Resource Book. New York: Routledge..

[12] Newmark, P. A (1988). Textbook of Translation. London: Prentice-Hall.

[13] Nida, E. A. and C. R. Taber. (1974) The Theory and Practice of Translation. Leiden.

[14] Simatupang, M. D. S. (1999) Pengantar Teori Terjemahan. Jakarta: Universitas Indonesia Press.

[15] Suryawinata, Z. and \& S. Hariyanto. (2003) Translation: Bahasan Teori dan Penuntun Praktis Menerjemahkan. Yogyakarta: Kanisius.

[16] Williams, J. and A. (2002) Chesterman. The Map: A Beginner's Guide to Doing Research in Translation Studies. Manchester: St. Jerome Publishing,. 